\title{
Amelioration of arthritis through mobilization of peptide-specific CD8+ regulatory T cells
}

\author{
Jianmei W. Leavenworth,1,2 Xiaolei Tang,, ${ }^{1,2}$ Hye-Jung Kim,1,2 \\ Xiaoyang Wang,,$^{1,2,3,4}$ and Harvey Cantor ${ }^{1,2}$
}

\begin{abstract}
1Department of Cancer Immunology and AIDS, Dana-Farber Cancer Institute, and 2Department of Microbiology and Immunobiology, Division of Immunology, Harvard Medical School, Boston, Massachusetts, USA. ${ }^{3}$ Perinatal Center, Department of Neuroscience and Physiology, Sahlgrenska Academy at University of Gothenburg, Gothenburg, Sweden. ${ }^{4}$ Department of Pediatrics, The Third Affiliated Hospital of Zhengzhou University, Zhengzhou, People's Republic of China.
\end{abstract}

\begin{abstract}
Current therapies to treat autoimmune disease focus mainly on downstream targets of autoimmune responses, including effector cells and cytokines. A potentially more effective approach would entail targeting autoreactive $T$ cells that initiate the disease cascade and break self tolerance. The murine MHC class Ib molecule Qa-1b (HLA-E in humans) exhibits limited polymorphisms and binds to 2 dominant self peptides: $\mathrm{Hsp60}_{\mathrm{p} 216}$ and $\mathrm{Qdm}$. We found that peptide-induced expansion of tetramer-binding CD8 ${ }^{+}$Tregs that recognize Qa-1-

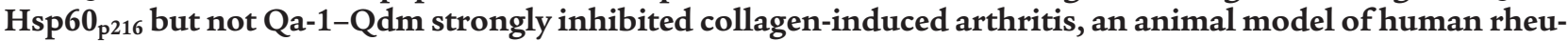
matoid arthritis. Perforin-dependent elimination of autoreactive follicular $T h\left(T_{\mathrm{FH}}\right)$ and Th17 cells by CD8 ${ }^{+}$ Tregs inhibited disease development. Infusion of in vitro-expanded $\mathrm{CD8}^{+}$Tregs increased the efficacy of methotrexate treatment and halted disease progression after clinical onset, suggesting an alternative approach to this first-line treatment. Moreover, infusion of small numbers of Qa-1-Hsp60 ${ }_{\mathrm{p} 216}$-specific $\mathrm{CD8}^{+}$Tregs resulted in robust inhibition of autoimmune arthritis, confirming the inhibitory effects of $\mathrm{Hsp}^{6 \mathrm{p}_{\mathrm{p} 216}}$ peptide immunization. These results suggest that strategies designed to expand Qa-1-restricted (HLA-E-restricted), peptidespecific $\mathrm{CD8}^{+}$Tregs represent a promising therapeutic approach to autoimmune disorders.
\end{abstract}

\section{Introduction}

RA is an autoimmune disorder characterized primarily by joint inflammation and erosion. The systemic nature of this disease is reflected in the involvement of multiple organ systems, including skin, lungs, and vasculature as well as diffuse tissue inflammation and increased risk of atherosclerosis (1). Although the identification of effector cytokines, including TNF, IL-1, and IL-6, that contribute to this disease has led to improved therapies, RA has remained relatively refractory to decisive intervention. More effective approaches to RA may require elimination of autoreactive $T$ cells, which, in turn depends on a precise definition of the Tregs that may target and eliminate the pathogenic $\mathrm{T}$ cell subsets that induce disease.

Here we analyze the contribution of Treg and effector $\mathrm{T}$ cell subsets to autoimmune arthritis in the collagen-induced arthritis (CIA) animal model. This murine disease model shares several similarities with human RA, including breach of self tolerance, generation of autoantibodies, inflammatory changes in multiple joints, and erosion of bone and cartilage accompanied by pannus formation (2). Murine CIA has been used to establish the potential efficacy of several FDA-approved RA therapies, including antiTNF Ab, IL-1 antagonists, and methotrexate $(\operatorname{MTX})(1,3)$.

The development of enlarged ectopic germinal centers (GCs) and the contribution of pathogenic autoantibodies in RA and in CIA has suggested that dysregulated follicular $\mathrm{Th}\left(\mathrm{T}_{\mathrm{FH}}\right)$ cell responses may contribute to ectopic GC formation and production of autoantibodies (4-6). A subset of $\mathrm{CD} 8^{+} \mathrm{T}$ cells, $\mathrm{CD} 8^{+}$Tregs, has been shown to efficiently inhibit $\mathrm{T}_{\mathrm{FH}}$ cells through recognition of MHC class Ib molecule Qa-1 expressed by this Th subset (5). However, the potential contribution of $\mathrm{CD}^{+}$Treg to the pathogenesis and treatment of this autoimmune disease is not well understood.

Conflict of interest: The authors have declared that no conflict of interest exists. Citation for this article: J Clin Invest. 2013;123(3):1382-1389. doi:10.1172/JCI66938.
$\mathrm{CD}^{+}$Tregs recognize the MHC class Ib molecule Qa-1b (HLA-E in humans) associated with peptide complexes that are upregulated by activated $\mathrm{CD}^{+} \mathrm{T}$ cells $(5,7)$. The 2 major peptides presented by Qa-1 (HLA-E) are Qdm (B7sp in humans) and Hsp60 2216 . The Qdm (Qa-1 determinant modifier) peptide is derived from the leader sequence of MHC class Ia, while the Hsp60 216 peptide is derived from the $60 \mathrm{kD}$ heat shock protein (Hsp60, p216-224). Differential expression of these Qa-1-peptide complexes on activated cells may allow detection of abnormally stressed cells in the context of infection, autoimmunity, or cellular transformation (8-11).

Here we investigate the impact of $\mathrm{CD}^{+}$Tregs on the development of CIA. We find that Qa-1-restricted CD8 ${ }^{+}$Tregs efficiently eliminate pathogenic $\mathrm{T}_{\mathrm{FH}}$ and Th17 cells and exert strong inhibitory effects on disease progression. Moreover, $\mathrm{CD}^{+}$Tregs that recognize complexes of Qa-1 and Hsp60 $0_{\mathrm{p} 216}$ peptide, but not Qdm peptide, can be mobilized through peptide-based immunization to inhibit development of autoimmune arthritis. The ability to expand Qa-1-restricted CD8 ${ }^{+}$Tregs based on their TCR specificity may represent a new and effective approach to treatment of autoimmune disease.

\section{Results}

Expansion of Qa-1-restricted $C D 8^{+}$Tregs inbibits arthritis. We reasoned that expansion of Qa-1-restricted $\mathrm{CD}^{+} \mathrm{T}$ cells in vivo might be achieved after immunization with the 2 major peptides that are bound by Qa-1 - Qdm and Hsp60 216 . The Qdm peptide, derived from the leader sequences of class Ia MHC proteins, is the dominant self peptide associated with Qa-1 at the cell surface. In addition, a peptide derived from the $60-\mathrm{kD}$ heat shock protein (Hsp60, p216-224) replaces the Qdm peptide upon cellular activation and/or stress $(12,13)$. To selectively expand

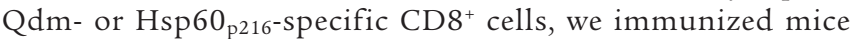
subcutaneously with peptide-pulsed $\mathrm{Kb}^{-/-} \mathrm{Db}^{-/-}$DCs that do not 
A $-\mathrm{DC}$

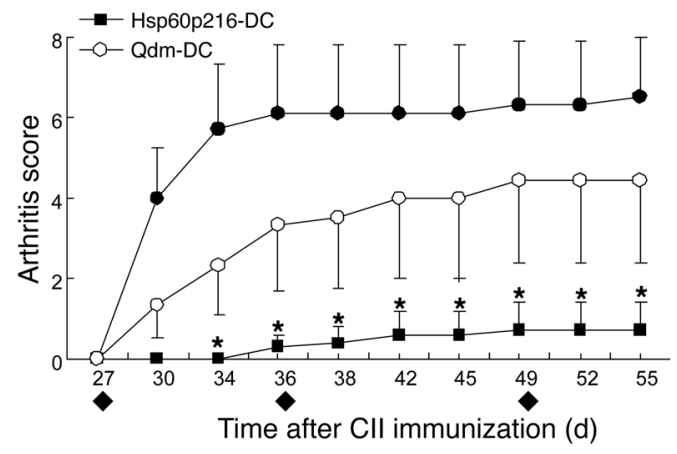

C
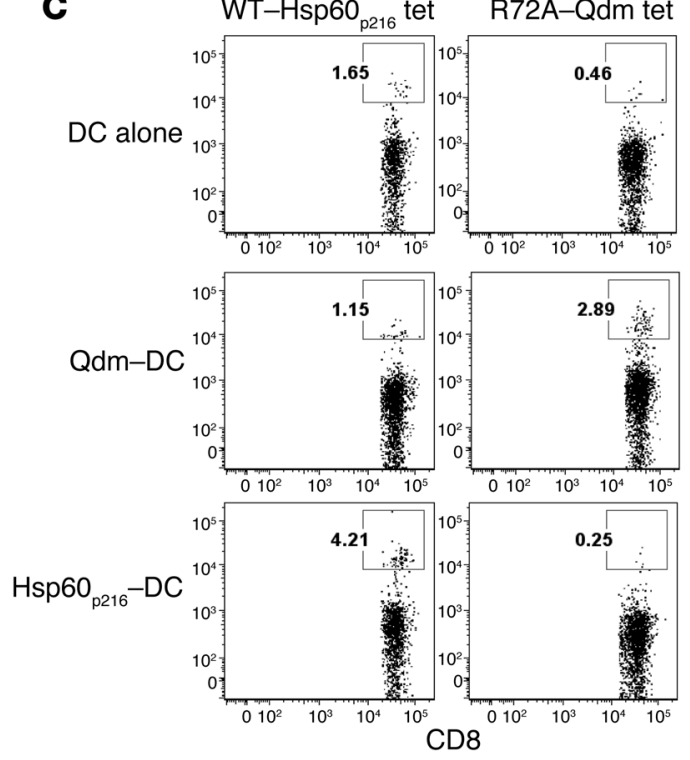

B
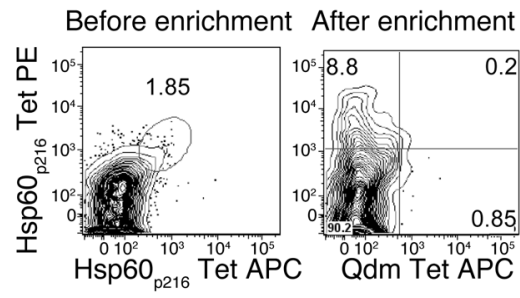

Peptide
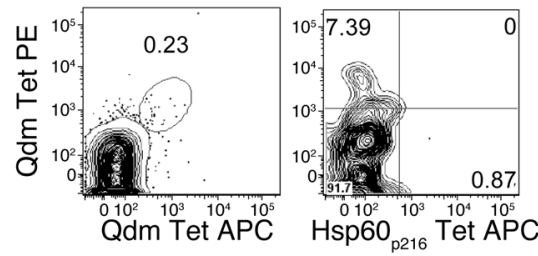

Qdm

\section{D}
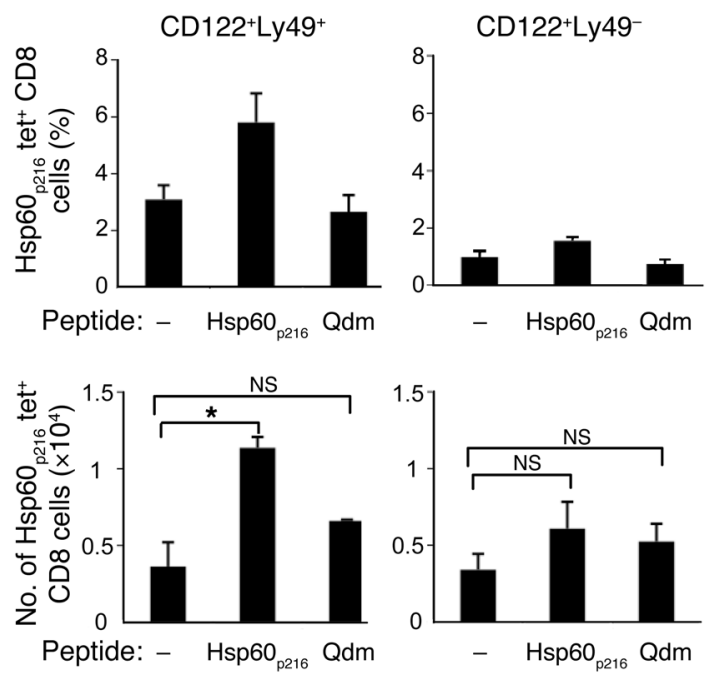

\section{Figure 1}

Selective expansion of Hsp60 ${ }_{\mathrm{p} 216^{-}}$-specific Qa-1-restricted CD8 ${ }^{+}$Tregs inhibits arthritis. (A) Arthritis was induced in B6 mice as described in Methods. Irradiated LPS-activated $\mathrm{Kb}^{-/-} \mathrm{Db} \mathrm{b}^{-/}$BM-derived DCs were loaded with or without $\mathrm{Hsp} 6 \mathrm{O}_{\mathrm{p} 216}$ or Qdm peptide and injected subcutaneously $\left(6 \times 10^{5}\right.$ mouse) at the tail base at day 27, day 36, and day 49 (diamonds). Arthritis scores are shown for 5-6 mice per group. The group injected with DCs alone versus the group given $\mathrm{Hsp} 0_{\mathrm{p} 216}$-loaded DCs differed significantly. ${ }^{*} P<0.05$. (B) Flow cytometry of dLN cells from Cll-immune B6 mice injected with DC-pulsed peptides as in A, after incubation with Qa-1 tetramers labeled with phycoerythrin (Tet-PE) or allophycocyanin (Tet-APC); analysis is shown before and after enrichment by magnetic bead columns for tet ${ }^{+} \mathrm{CD} 8^{+}$cells. Numbers in plots before enrichment and after enrichment (upper left quadrant) indicate percentage of tet+ ${ }^{+} \mathrm{CD} 8^{+}$cells. (C) B6 mice were immunized with either unpulsed $K b^{-/-} \mathrm{Db} b^{-/-} \mathrm{DCs}$ or DCs that had been loaded with the indicated peptide as described in A. CD8+ cells from dLNs from each group were analyzed at day 42 for

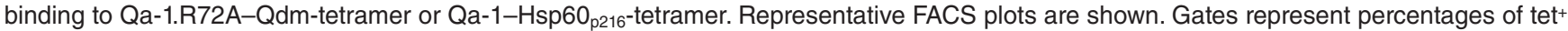

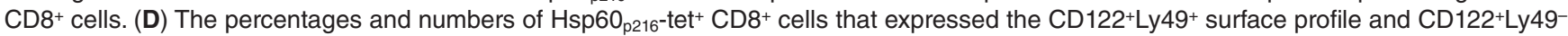
surface profile are shown. ${ }^{*} P<0.05$.

express class Ia MHC, but express high levels of class Ib MHC, including Qa-1. Immunization of mice with Hsp60 $60_{\mathrm{p} 216^{-}}$but not Qdm-pulsed $\mathrm{Kb}^{-/-} \mathrm{Db}^{-/-}$DCs during the course of CIA inhibited the development of arthritis (Figure 1A).

We then generated Qa-1-peptide tetramers (tet) to determine the frequency of peptide-specific $\mathrm{CD}^{+} \mathrm{T}$ cells. In the case of Qa-1-Qdm tetramers, a Qa-1 protein containing a point mutation (R72A) was used to prevent binding of Qa-1-Qdm to CD94/ NKG2A receptors (14) and allow specific detection of $\mathrm{CD}^{+} \mathrm{T}$ cells that express Qa-1-restricted TCR (Supplemental Figure 1A; supplemental material available online with this article; doi:10.1172/JCI66938DS1). We labeled cells with tetramers con- jugated to 2 different fluorophores to increase specificity, followed by magnetic enrichment of cells positive for relative Qa-1peptide tetramers as described (refs. 10, 15, and Figure 1B). Enrichment for $\mathrm{CD}^{+} \mathrm{T}$ cells with the Qa-1-peptide tetramers was specific, since we detected only background frequency of Qa-1-peptide tet ${ }^{+} \mathrm{CD}^{+} \mathrm{T}$ cells from transgenic mice expressing a TCR specific for the unrelated OT-1 peptide (Supplemental Figure $1 \mathrm{~B}$ ). Moreover, $\mathrm{CD}^{+} \mathrm{T}$ cells that bound to the $\mathrm{Qa}-1-$ Hsp60 $0_{\mathrm{p} 216}$ tetramer do not bind to the Qa-1-Qdm tetramer and vice versa (Figure 1B).

This tetramer-based analysis revealed that expansion of Qa-1Hsp60 $0_{\mathrm{p} 216^{-}}$specific CD8 ${ }^{+} \mathrm{T}$ cells as detected by Qa-1-Hsp60 $0_{\mathrm{p} 216}$ 
A

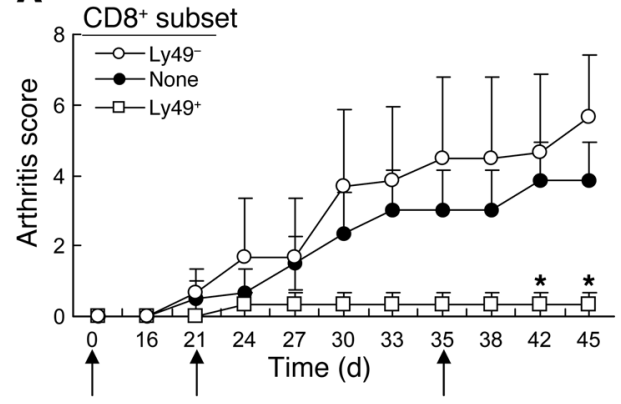

C

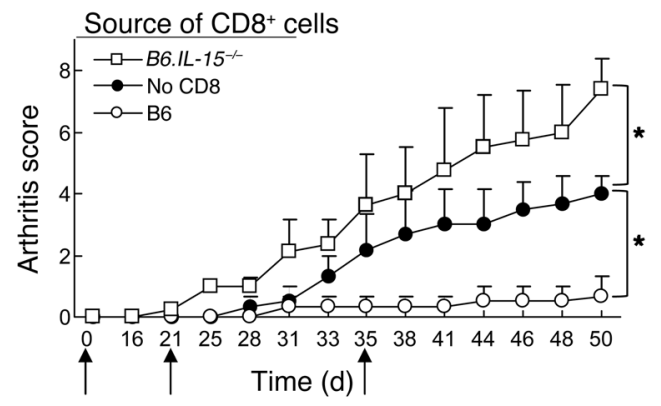

B

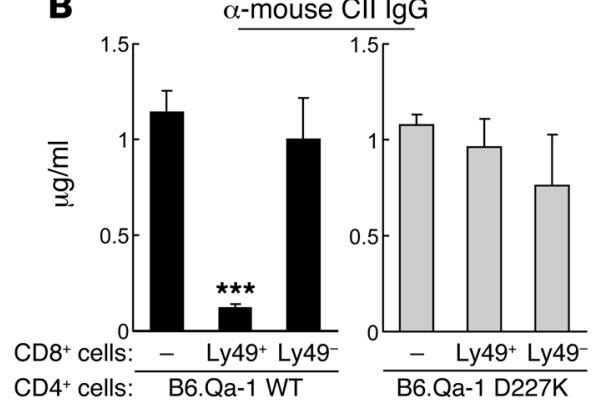

D

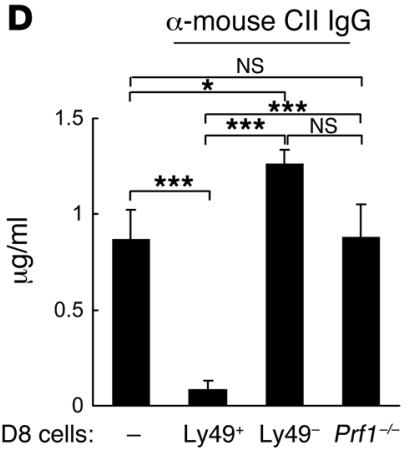

Figure 2

Infusion of CD122+CD44hil Ly49+ CD8 ${ }^{+}$Tregs inhibits arthritis development. (A) Purified CD25- CD4+ cells $\left(1 \times 10^{6}\right)$ and B cells $\left(2 \times 10^{6}\right)$ from arthritic mice were cotransferred into Rag2 ${ }^{-1-P r f 1^{-/}}$mice at day 0 with or without CD122+CD44hiLy49+ or Ly49- CD8 ${ }^{+}$cells $\left(1.5 \times 10^{5}\right)$ FACS-sorted from cCllimmunized B6 mice. Mice were immunized at day 0 and boosted at days 21 and 35 (black arrows) with cCll. Arthritis scores are shown for 5 mice/group. ${ }^{\star} P<0.05=$ group (none) versus group (Ly49+ CD8). Representative data from 5 independent experiments are shown. (B) Adoptive transfer of B6.WT or B6.D227K CD4+ cells and WT B cells with or without Ly49+ CD8+ cells or Ly49- CD8+ cells. Arthritis was induced as in A. Serum titers of anti-mouse CII lgG were measured at day 45. (C) Adoptive transfer of B6.WT CD4 ${ }^{+}$cells and B cells with or without CD8 ${ }^{+}$Treg or CD44hi CD8 ${ }^{+}$cells $\left(1.5 \times 10^{5}\right)$ from B6. $/ L 15^{+/+}$ or B6.IL15 $15^{-1}$ mice. Arthritis was induced as in $\mathbf{A}$ and scores are shown. (D) Adoptive transfer of CD4+ cells and $B$ cells with $1.5 \times 10^{5}$ CD122+CD44hiLy49+ or CD122+CD44hiLy49- CD8 ${ }^{+}$cells or CD8 ${ }^{+}$cells from cCll-immunized WT or Prf1/- mice as described in A. Serum titers of anti-mouse CII IgG were measured at day $45 .{ }^{*} P<0.05 ;{ }^{* * *} P<0.001$.

tetramers after immunization with Hsp60 216 -pulsed DCs inhibited the development of CIA (Figure 1, C and D). Although immunization with Qdm-pulsed $\mathrm{Kb}^{-/-} \mathrm{D} \mathrm{b}^{-/-}$DCs resulted in increased numbers of Qa-1 R72A-Qdm tet ${ }^{+}$cells that include both CD $122^{+} \mathrm{Ly}_{49}{ }^{+}$and $\mathrm{CD} 122^{+} \mathrm{Ly} 49^{-}$populations (ref. 16, Figure 1C, and Supplemental Figure 1, C and D), this immunization did not inhibit disease development (Figure 1A). Although T cells specific for several other Hsp60 epitopes have been detected in juvenile idiopathic arthritis patients along with expansion of CD $4^{+}$Tregs (17), Hsp $60_{\mathrm{p} 216}$ immunization did not change the frequency of Foxp $3^{+} \mathrm{CD}^{+}$cells (Supplemental Figure 1E). We also noted that Hsp60 216 immunization resulted in expansion of Hsp60 216 -tet ${ }^{+}$ $\mathrm{CD}^{+}$cells within the CD122+ ${ }^{+} 49^{+}(16)$ but not the CD $122^{+}$Ly $49^{-}$ CD8 subset (Figure 1D). These results suggest that Hsp60 $216^{-}$ Qa-1-restricted $\mathrm{CD}^{+}$cells belonging to the $\mathrm{CD} 122^{+} \mathrm{Ly} 49^{+} \mathrm{CD}^{+}$ subset may inhibit autoimmune arthritis.

Infusion of $C D 8^{+}$Tregs inhibits arthritis development. The above find-

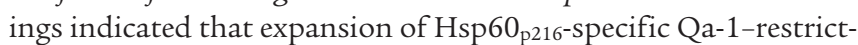
ed $\mathrm{CD}^{+}$cells (but not control Qa-1-restricted peptide) was associated with disease inhibition. Infusion of the fewer than $5 \%$ of $\mathrm{CD}^{+}$ $\mathrm{T}$ cells expressing the triad of surface receptors that characterize
$\mathrm{CD}^{+}$Tregs $\left(\mathrm{CD} 122^{+} \mathrm{CD} 44^{+} \mathrm{Ly} 49^{+}\right.$; triad $^{+}$) into adoptive hosts that had been given $\mathrm{CD} 25^{-} \mathrm{CD} 4^{+} \mathrm{T}$ cells and $\mathrm{B}$ cells from chicken type II collagenimmune (cCII-immune) donors abolished disease progression (Figure $2 \mathrm{~A}$ ) and reduced titers of anti$\mathrm{CII} \mathrm{Ab}$ (Figure 2B). In contrast, infusion of CD $122^{+} \mathrm{CD} 44^{+} \mathrm{Ly} 49$ $\mathrm{CD}^{+}$cells failed to inhibit disease progression. The inhibitory activity of $\mathrm{Ly}^{4} 9^{+} \mathrm{CD}^{+} \mathrm{T}$ cells depended on recognition of Qa-1 expressed by $\mathrm{CD}^{+}$Th cells, since CD $4^{+}$Th cells expressing a $\mathrm{Qa}-1$ point mutation (Qa-1 D227K) that impaired recognition by $\mathrm{CD}^{+}$cells $(5,18)$ were resistant to $\mathrm{CD}^{+}$Treg-dependent inhibition (Figure 2B).

$\mathrm{CD} 8^{+}$Treg activity depends on perforin and $I L-15$ expression. To further investigate the mechanism of suppression by $\mathrm{Ly} 49^{+} \mathrm{CD}^{+}$Tregs, we asked whether suppression by the Ly $49^{+} \mathrm{CD}^{+}$cells depended on IL- 15 . Transfer of CD8 ${ }^{+}$cells from $I L-15^{-/-}$ donors failed to inhibit disease severity; indeed, an increase in disease intensity was noted (Figure 2C). Suppression also reflected perforindependent elimination, since purified Prf1-deficient CD8 ${ }^{+} \mathrm{T}$ cells did not reduce anti-mouse collagen $\mathrm{Ab}$ responses (Figure 2D). In sum, IL-15 was essential to the development of CD $122^{+} \mathrm{CD} 44^{+} \mathrm{Ly} 49^{+} \mathrm{CD}^{+}$ Tregs, and intracellular perforin was required for expression of suppressive activity.

$\mathrm{CD}^{+}$Tregs inhibit arthritis through Qa-1-dependent elimination of pathogenic $T_{F H}$ and Th17 cells. We then investigated the cellular targets of $\mathrm{CD}^{+}$Tregs. Expansion of collagen-reactive $\mathrm{CD} 4^{+} \mathrm{T}$ cells is associated with the development of CIA. Examination of effector $\mathrm{CD}^{+}{ }^{+} \mathrm{T}$ cells during the course of CIA revealed that both $\mathrm{CD} 4^{+} \mathrm{T}_{\mathrm{FH}}$ $\left(\mathrm{ICOS}^{+} \mathrm{CXCR}^{+}\right.$or $\left.\mathrm{ICOS}^{+} \mathrm{BTLA}^{+}\right)$and $\mathrm{CD} 4^{+} \mathrm{IL}-17^{+}$cells in all LNs (not only LNs draining the site of cCII immunization) increased 10- to 20-fold during disease progression (Supplemental Figure 2, A and B), while IFN- $\gamma^{+} \mathrm{CD} 4^{+}$cells were increased to a lesser extent ( $\sim 5$-fold) (Supplemental Figure 2$)$. Analysis of cellular infiltrates in arthritic joints revealed that approximately $50 \%$ of $\mathrm{CD}^{+}$cells expressed the ICOS and CXCR5 pair, characteristic of $\mathrm{T}_{\mathrm{FH}}$ cells (Supplemental Figure 2). Th17 cells were also detected in inflamed joints, albeit at lower frequencies (Supplemental Figure 2C). Increased numbers of $\mathrm{T}_{\mathrm{FH}}$ cells were associated with expansion of GC B cells and increased titers of IgG anti-CII autoantibody, and adoptive transfer of $\mathrm{T}_{\mathrm{FH}}$ (but not Th17) cells along with $\mathrm{B}$ cells induced robust anti-CII autoantibody production (Figure $3 \mathrm{~A}$ and Supplemental Figure 2). Although transfer of large numbers of

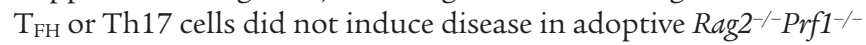
hosts, transfer of both Th subsets induced strong disease (19). 
A

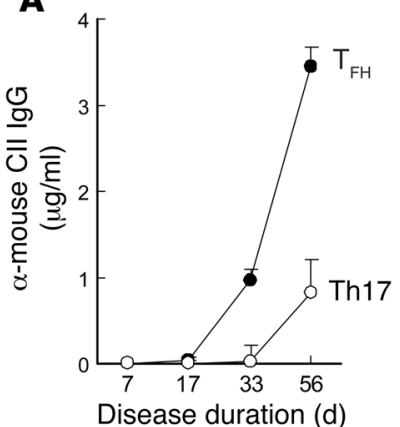

D

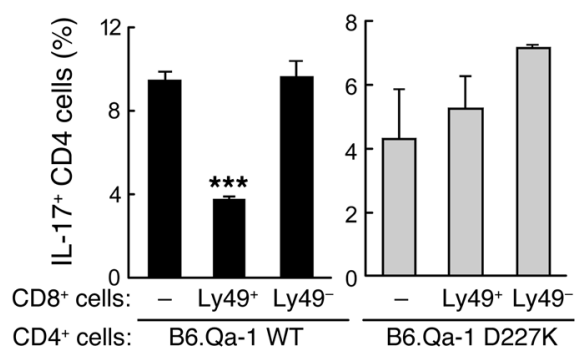

B

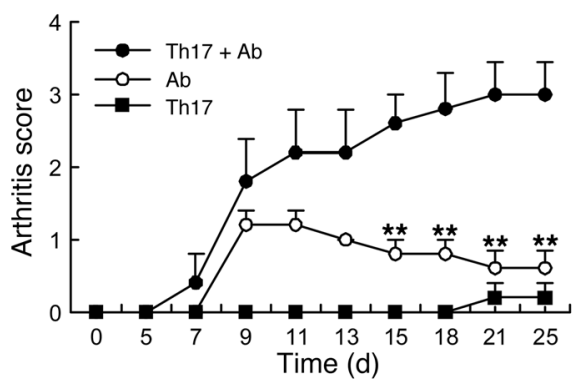

E
C

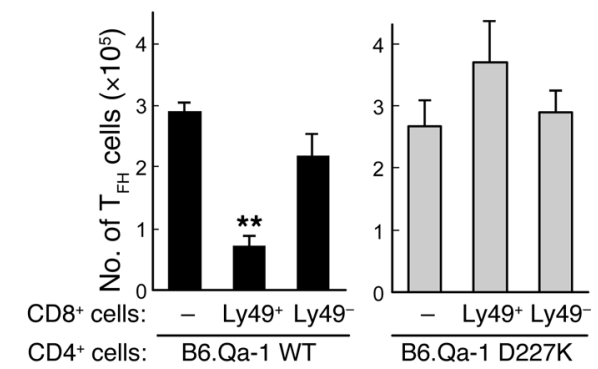

\section{Figure 3}

Inhibition of arthritis by $\mathrm{CD}^{+}$Tregs is associated with targeting of pathogenic $\mathrm{T}_{\mathrm{FH}}$ and Th17 cells. (A) $\mathrm{T}_{\mathrm{FH}}$ cells $\left(\mathrm{ICOS}+\mathrm{CXCR}^{+} 5^{+B T L A+} \mathrm{CD} 4^{+}\right.$cells)

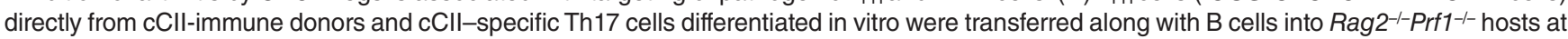
day 0 . Arthritis was induced as described in Methods. Serum titers of anti-mouse CII IgG at the indicated time points are shown. (B) Anti-collagen II $\mathrm{Ab}(1 \mathrm{mg})$ was injected intraperitoneally into Rag2-l-Prf1-l- hosts with or without cotransfer of in vitro-generated cCll-specific Th17 cells $\left(2 \times 10^{6}\right)$ before all recipients were immunized with cCll. Arthritis scores are shown for 5 mice/group. ${ }^{* *} P<0.01$, group (Ab alone) versus group (Th17 $+\mathrm{Ab}$ ). Data are representative of 5 independent experiments. (C and D) Adoptive transfer of B6.WT or B6.D227K CD4+ cells and WT B cells with or without Ly $49^{+} \mathrm{CD} 8^{+}$cells or Ly49-CD8 ${ }^{+}$cells as in Figure $2 \mathrm{~A}$. The effect on splenic $\mathrm{T}_{\mathrm{FH}}$ cells (C) or percentage of IL-17 $7^{+} \mathrm{CD} 4^{+}$cells (D) at day 45 is shown. (E) ICOS ${ }^{+} \mathrm{CXCR} 5^{+} \mathrm{BTLA}^{+} \mathrm{CD} 25^{-}\left(\mathrm{T}_{\mathrm{FH}}\right) \mathrm{CD}^{+}$cells $\left(2 \times 10^{6}\right)$ sorted from arthritic mice $($ score $=12)$ and cCll-specific Th17 cells generated

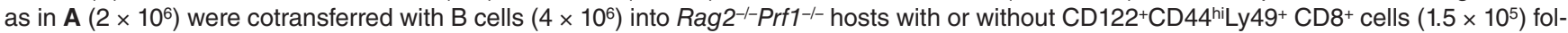
lowed by arthritis induction by cCll injections on days 0,21 , and 32 (black arrows). Arthritis scores are shown on left. On right, serum anti-mouse CII IgG titers at day 45 are shown. ${ }^{\star} P<0.05 ;{ }^{\star \star} P<0.01 ;{ }^{\star \star \star} P<0.001$.

We tested the hypothesis that disease might reflect a $\mathrm{T}_{\mathrm{FH}^{-}}$ induced autoantibody response combined with a Th17-dependent inflammatory reaction. Indeed, mice given Th17 cells and autoantibody (mainly anti-CII Ab) in place of $\mathrm{T}_{\mathrm{FH}}$ cells developed severe and sustained arthritis (Figure 3B). These data suggest that CIA initiation in intact animals may reflect a synergistic interaction in which a Th17-mediated inflammatory response enhances a $\mathrm{T}_{\mathrm{FH}^{-}}$ dependent autoantibody production.

These results also suggested that inhibition of the $\mathrm{T}_{\mathrm{FH}}$ and Th17 cell response might interrupt early events in the autoimmune disease process. Indeed, reduced arthritis and autoantibody titers in recipients of $\mathrm{CD}^{+}$Tregs were associated with diminished numbers of $\mathrm{T}_{\mathrm{FH}}$ and Th17 cells (Figure 3, C and D), but not IFN- $\gamma^{+}$ (Th1) cells in adoptive hosts (Supplemental Figure 3). Elimination of $\mathrm{T}_{\mathrm{FH}}$ and Th17 cells required perforin expression by $\mathrm{Ly} 49^{+} \mathrm{CD}^{+}$ Tregs (Supplemental Figure 4) and depended on Qa-1 expression by $\mathrm{CD} 4^{+}$Th target cells, since $\mathrm{CD} 4^{+}$Th cells expressing a $\mathrm{Qa}-1$ point mutation (Qa-1 D227K) that impaired recognition by $\mathrm{CD}^{+}$ cells $(5,18)$ were resistant to elimination (Figure $3, C$ and D).

To further define the mechanism of Treg-dependent inhibition

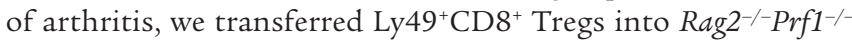
hosts reconstituted with isolated $\mathrm{T}_{\mathrm{FH}}$ cells $\left(\mathrm{ICOS}^{+} \mathrm{CXCR} 5^{+} \mathrm{BTLA}^{+}\right)$ and Th17 cells. Cotransfer of $\mathrm{T}_{\mathrm{FH}}$ and Th17 cells induced clinical arthritis; infusion of $\mathrm{Ly}_{4} 9^{+} \mathrm{CD} 8{ }^{+}$Tregs diminished disease progres- sion and significantly reduced anti-CII Ab titers (Figure 3E), supporting the conclusions drawn from experiments using unseparated $\mathrm{CD} 4^{+}$cells (Figure $3, \mathrm{C}$ and D).

Transfer of in vitro IL-15C-expanded $C D 8^{+}$Tregs inbibits CIA. We further defined the contribution of IL-15 to the suppressive activity of $\mathrm{CD}^{+}$Tregs in experiments that analyzed the effects of incubation of $\mathrm{CD}^{+}$Tregs with low concentrations of IL-15/IL-15R $\alpha$ complexes (IL-15C) $(20,21)$. Ly49+ ${ }^{+} \mathrm{CD}^{+} \mathrm{T}$ cells incubated in vitro for 1 week in the presence of $10 \mathrm{ng} \mathrm{ml}^{-1} \mathrm{IL}-15 \mathrm{C}$ maintained their surface phenotype (Supplemental Figure 5) after vigorous expansion: approximately $3 \times 10^{6} \mathrm{CD} 122^{+} \mathrm{CD} 44^{+} \mathrm{Ly} 49^{+} \mathrm{CD} 8^{+}$cells were generated within 7 days from an initial seeding of $10^{5} \mathrm{CD}^{+}$cells that expressed the same triad of surface receptors. Moreover, these in vitro-expanded $\mathrm{CD}^{+}$Tregs abolished anti-mouse collagen $\mathrm{Ab}$ responses (Figure $4 \mathrm{~A}$ ) and efficiently inhibited disease development in Rag2 $2^{-/}$Prf $1^{-/}$hosts given cCII-immune $\mathrm{CD}^{+} \mathrm{T}$ cells (Figure 4B). The inhibitory activity of IL-15C-incubated $\mathrm{CD}^{+}$Tregs was at least as potent as that of nonincubated $\mathrm{CD}^{+}$Tregs (Figure 4B compared with Figure 2A), suggesting that infusion of in vitro IL-15-expanded $\mathrm{CD}^{+}$Tregs may represent an effective therapeutic approach to CIA. Moreover, transfer of in vitro-expanded $\mathrm{CD}^{+}$Tregs into unirradiated C57BL/6 (B6) mice followed by immunization with cCII suppressed arthritis progression (Figure 4C and Supplemental Figure $6 \mathrm{~A}$ ) and reduced $\mathrm{T}_{\mathrm{FH}}$ and Th17 cell numbers (Figure 4D and Supplemental Figure 6B) in 
A

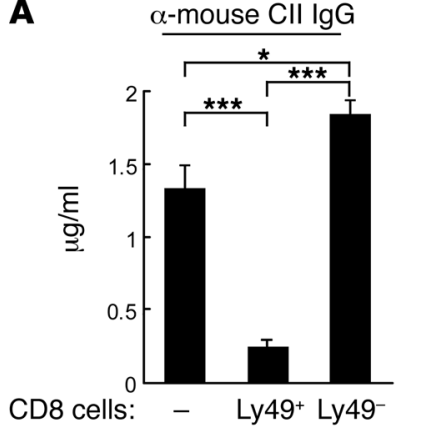

B

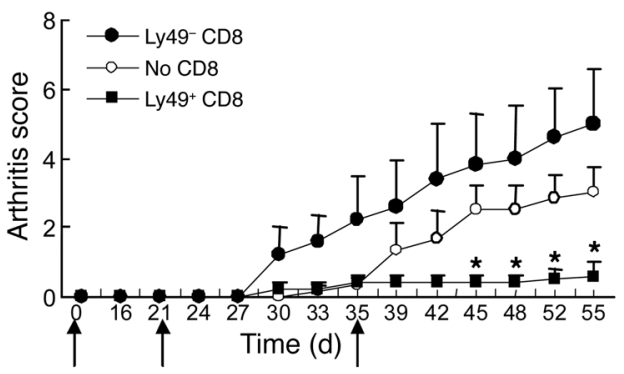

C

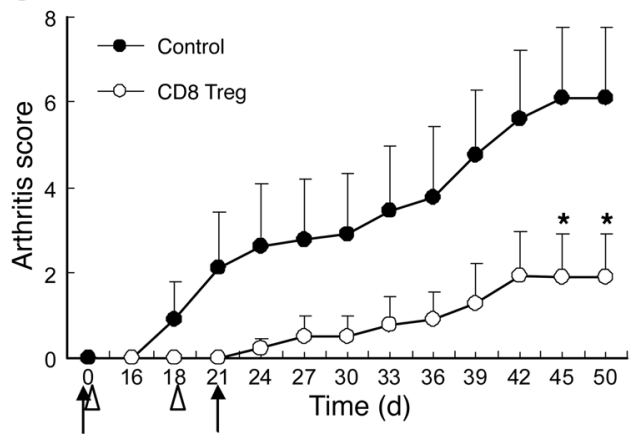

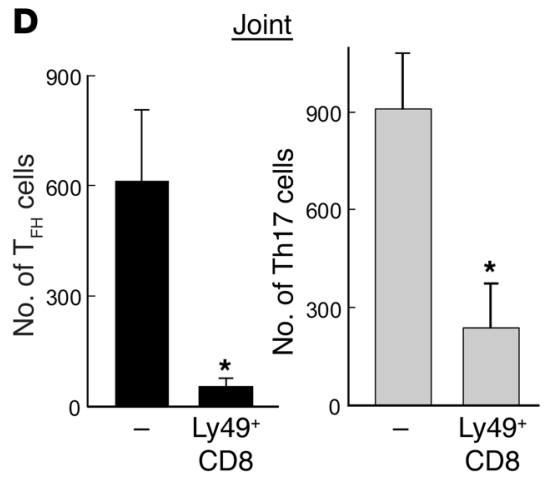

$\mathbf{E}$

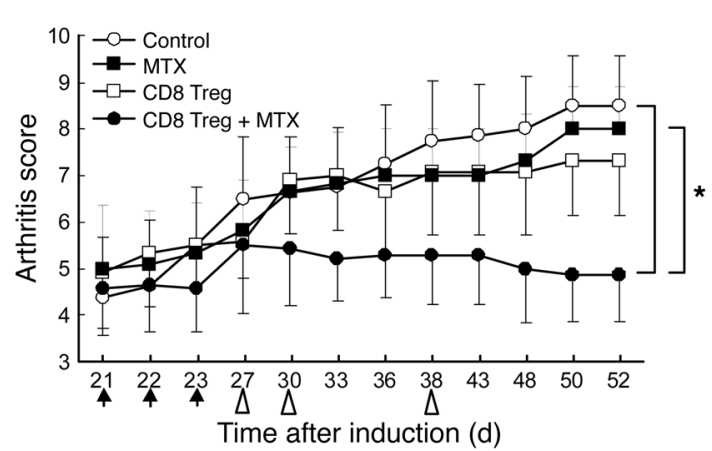

Figure 4

Transfer of in vitro IL-15C-expanded CD8 ${ }^{+}$Tregs inhibits CIA. (A) CD122+CD44hil ${ }^{+} 49^{+}$or CD122+CD44hiLy49- CD8 ${ }^{+}$cells sorted from cCllimmunized $\mathrm{B} 6$ mice were incubated in $10 \mathrm{ng} \mathrm{ml}^{-1} \mathrm{IL}-15 \mathrm{C} \times 1$ week. Purified CD25- CD4 ${ }^{+}$and $\mathrm{B}$ cells from arthritic donors were transferred with

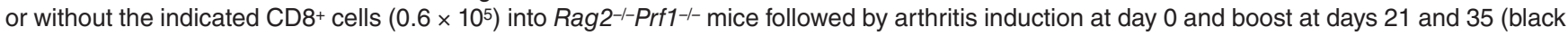
arrows). Serum titers of anti-mouse CII lgG are shown. ${ }^{* *} P<0.001$. (B) Arthritis scores are shown for $5-6$ mice/group. Group (no CD8) vs. group (Ly49+CD8), ${ }^{*} P<0.05$. Data represent 3 independent experiments. (C) In vitro-expanded CD $122+$ CD 44 hil Ly $49^{+}$CD $8+$ cells $\left(2 \times 10^{5}\right)$ were transferred into B6 mice at days 0 and 18 (triangles). cCll immunization and boosting at days 0 and 21 (black arrows) and arthritis scores over 50 days are shown. (D) Numbers of $\mathrm{T}_{\mathrm{FH}}$ and IL-17-expressing CD4+ cells from inflamed joints in $\mathbf{C}$ are shown for 5-6 mice/group. (E) $0.75 \mathrm{mg} / \mathrm{kg}$ MTX was injected into B6 mice from day 21 to day 23 (arrows) after development of arthritis (average score of 4.5). In vitro IL-15C-expanded CD122 ${ }^{+}$CD 44hil Ly 49 ${ }^{+}$CD8 ${ }^{+}$cells $\left(2.5 \times 10^{5}\right)$ were transferred into mice at days 27,30 , and 38 (triangles). Arthritis scores are shown for $5-8$ mice/ group. Group (control) or group (MTX) versus group $\left(\mathrm{CD} 8^{+}\right.$Treg $\left.+\mathrm{MTX}\right)$ difference: ${ }^{*} P<0.05$.

both spleen (data not shown) and inflamed joints, reflecting a broad elimination of potential effector Th activity.

Combination of $C D 8^{+}$Tregs and MTX exerts therapeutic effects on ongoing disease. MTX, the disease-modifying anti-rheumatic drug $(22,23)$, is thought to prevent arthritis through inhibition of inflammation and joint destruction at the level of synoviocytes (24). In contrast, $\mathrm{CD}^{+}$Tregs interrupt the autoimmune pathway much earlier (e.g., see Figure 2). We therefore studied the combined effects of an MTX pulse to block joint inflammation followed by infusion of $\mathrm{CD}^{+}$Tregs at later time points to prevent new damage inflicted by a continuing systemic autoimmune response. Attenuation of disease activity was noted using an MTX pulse of $1.5 \mathrm{mg} / \mathrm{kg}$ over a short time period (from day 21 to day 23) (Supplemental Figure 7, A and B), while doses lower than $0.75 \mathrm{mg} / \mathrm{kg}$ had minimal effects on disease progression (Supplemental Figure 7, A-C). Coadministration of MTX at $0.75 \mathrm{mg} / \mathrm{kg}$ with $\mathrm{CD}^{+}$Tregs resulted in a marked reduction in disease severity (Figure 4E). The synergistic therapeutic effect of this combination therapy may depend, in part, on the failure of low doses of MTX to diminish the numbers of CD $122^{+} \mathrm{Ly}^{4} 9^{+} \mathrm{CD}^{+}$cells (Supplemental Figure 7 and ref. 16). Together, these results suggest the potential contribution of therapy using $\mathrm{CD}^{+}$Tregs and MTX to ameliorate ongoing disease.
Transfer of $\mathrm{CD}^{+}$Tregs specific for Qa-1-Hsp60 216 inhibits arthritis. The IL-15 dependence of CD8 ${ }^{+}$Tregs allowed us to directly test the hypothesis raised by the results of Figure 1: Hsp $60_{\mathrm{p} 216-\mathrm{Qa}-1-}$ restricted $\mathrm{CD}^{+}$cells mediate $\mathrm{CD}^{+}$Treg activity. We separated Qa-1-Hsp60 ${ }_{\mathrm{p} 216}$-tet $^{+} \mathrm{CD} 8^{+}$cells from the tet ${ }^{-}$fraction by consecutive FACS sorting and microbead selection (Figure 5A). After in vitro expansion of enriched tet ${ }^{+} \mathrm{CD}^{+}$cells by IL-15C, adoptive transfer

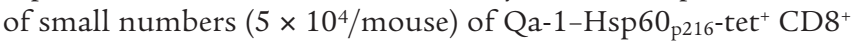
cells, but not Qa-1 R72A-Qdm-tet ${ }^{+} \mathrm{CD}^{+}$cells, into Rag2 $2^{-/-} \mathrm{Prf1}^{-{ }^{--}}$ hosts along with cCII-immune CD4 and B cells inhibited autoantibody production and halted arthritis progression (Figure 5, B-E). Analysis of $\mathrm{CD}^{+}$cells in these adoptive hosts

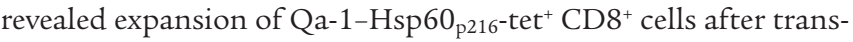
fer of tet ${ }^{+}$but not tet ${ }^{-} \mathrm{CD} 8^{+}$cells (Figure $5 \mathrm{C}$ ). Moreover, transfer of Qa-1 R72A-Qdm tet ${ }^{+} \mathrm{CD}^{+}$cells did not inhibit autoantibody production (Figure 5E), consistent with the failure of Qdm immunization to suppress CIA (Figure 1).

\section{Discussion}

Clinical approaches to the treatment of arthritis have focused mainly on downstream elements of this disease process, while sparing the initiating autoimmune events including induction 
A

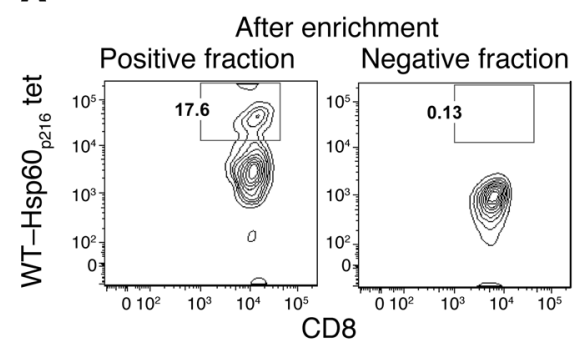

B

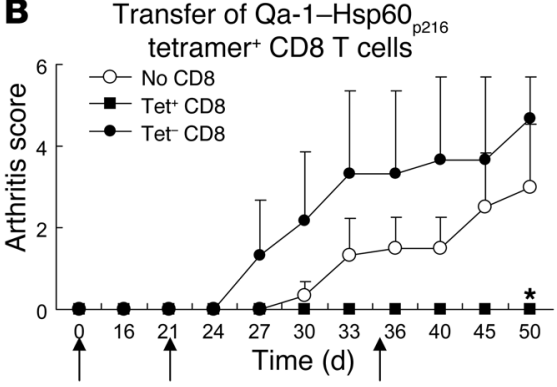

C

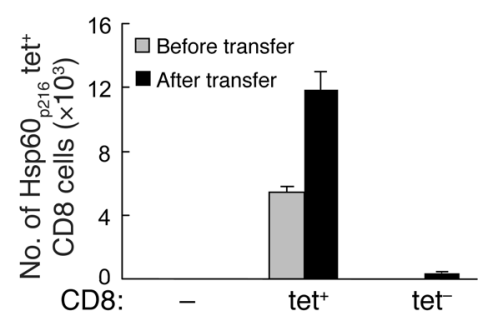

D $\alpha$-mouse CII IgG

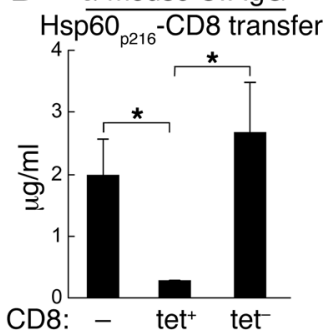

Figure 5

Transfer of Qa-1-Hsp60 $\mathrm{p} 216_{6}$ restricted CD8+ Treg inhibits arthritis. (A) Hsp60 p216-tet $^{+}$and Hsp60 p216- $^{-}$ tet $\mathrm{CD}^{+}$cells were sorted from cCll-immune B6 mice that had been immunized 2 weeks earlier with $\mathrm{Kb}^{-/-} \mathrm{Db} \mathrm{b}^{-/} \mathrm{DCs}$ loaded with Hsp60 $\mathrm{p} 216_{6}$ before incubation in IL-15C $\left(10 \mathrm{ng} \mathrm{ml}^{-1}\right) \times 10$ days. After incubation with $\mathrm{Hsp} 60_{\mathrm{p} 216}$ tetramer and enrichment by anti-PE microbeads, they were subjected to FACS analysis. Incubation of $\mathrm{CD} 8^{+}$cells that were initially tet ${ }^{+}$resulted in a substantial increase and enrichment of tet ${ }^{+} \mathrm{CD} 8^{+}$cells; identical incubation of $\mathrm{CD} 8^{+}$cells that were tet did not result in significant levels of tet ${ }^{+}$cells after incubation in IL-15C. Hsp60 ${ }_{\mathrm{p} 216}$-tet $^{+}$or $\mathrm{Hsp}_{\mathrm{p} 216} \mathrm{tet}^{-}$fraction of $\mathrm{CD}^{+}$cells was transferred into Rag $2^{-1-} \mathrm{Prf1}^{-/-}$mice at day 0 along with CD4 and B cells from arthritic mice. Mice were immunized at day 0 and boosted at days 21 and 35 (black arrows) with cCll. Arthritis scores (B), numbers of splenic Hsp60 $\mathrm{p} 216$-tet $^{+} \mathrm{CD} 8^{+}$cells at day 34 (C), and anti-mouse CII IgG titers at day 30 (D) after adoptive transfer are shown for 3-5 mice per group. Group (tet CD8) versus group (tet ${ }^{+} \mathrm{CD} 8$ ), ${ }^{*} P<0.05$. (E) By comparison, transfer of $\mathrm{Qdm}$-tet ${ }^{+}$(or tet) $\mathrm{CD}^{+}$cells had no significant effect on the response of $\mathrm{CD}^{+}$and $\mathrm{B}$ cells from arthritic mice using the same conditions (D).

of autoantibodies and inflammatory responses by autoimmune Th cells. Here, we describe a strategy that depends on targeting of pathogenic $\mathrm{T}_{\mathrm{FH}}$ and Th17 cells by $\mathrm{CD} 8^{+}$Tregs.

$\mathrm{CD}^{+}$Treg treatment was particularly effective at blunting the autoantibody response in CIA (e.g., Figures 2 and 3 ). Since CD8 ${ }^{+}$ Tregs target $\mathrm{T}_{\mathrm{FH}}$ cells and Th17 cells, the major Th subsets that induce the humoral and inflammatory components of CIA, we asked whether infusion of $\mathrm{CD} 8^{+}$Tregs might therefore confer durable inhibition of this autoimmune disorder. Transfer of $\mathrm{CD} 122^{+} \mathrm{CD} 44^{+} \mathrm{Ly} 49^{+} \mathrm{CD}^{+}$cells, which represents less than $5 \%$ of the total $\mathrm{CD}^{+}$cell population and carries essentially all $\mathrm{CD}^{+}$ Treg activity (16), resulted in reduction of the numbers of $\mathrm{T}_{\mathrm{FH}}$ and Th17 cells and robust inhibition of disease. The finding that $\mathrm{CD}^{+}$Tregs inhibit $\mathrm{T}_{\mathrm{FH}}$ and Th17 $\mathrm{CD} 4^{+}$cells but do not target Th1 cells suggests direct targeting of Th subsets, consistent with previous findings (5). However, the possibility that activated DCs that upregulate the Qa-1-peptide complexes may also be targeted by $\mathrm{CD}^{+}$Tregs cannot be excluded. Although definition of the precise target cells requires further analysis, the low frequency of $\mathrm{CD}^{+}$ Tregs found in arthritic synovia ( $<1 \%$ of total $\mathrm{T}$ cells) suggests that the inhibitory activity of $\mathrm{CD}^{+}$Tregs is exerted within the systemic lymphoid organs rather than arthritic joints.

Although defective $\mathrm{CD}^{+}\left(\mathrm{Foxp}^{+}\right)$Treg activity has been reported in CIA (25-27), regulatory $\mathrm{CD} 4^{+}$cells may not result in sustained disease inhibition $(28,29)$, consistent with our find-
E $\alpha$-mouse $\mathrm{CII} \lg \mathrm{G}$ $\frac{\alpha \text {-mous }- \text { CD8 transfer }}{4}$

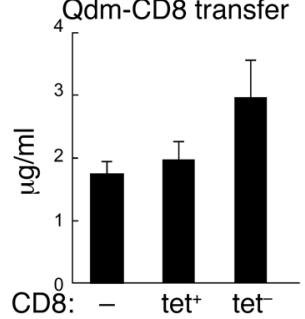

ings (Supplemental Figure 8). Possibly, impairment of $\mathrm{CD}^{+}$Treg activity in the context of an inflammatory milieu associated with CIA may limit this approach (30). Although the recently defined $\mathrm{CXCR}^{+}$follicular $\mathrm{CD}^{+}$Treg $\left(\mathrm{T}_{\mathrm{FR}}\right)$ can suppress GC responses $(31,32)$, whether this $\mathrm{CD}^{+}$Treg subset can target $\mathrm{T}_{\mathrm{FH}}$ cell activity and reduce CIA remains to be determined.

Incubation of CD $122^{+} \mathrm{Ly} 49^{+} \mathrm{CD}^{+}$ cells with IL-15/IL- $15 \mathrm{R} \alpha$ complexes induced robust expansion of these cells, which retained potent disease inhibitory activity, possibly reflecting the ability of 2 canonical CD8 ${ }^{+}$Treg surface receptors - Ly49F and CD122 - to reduce the threshold for IL-15 activation (33). Although the contribution of IL-15 to the development and regulation of autoimmune disease has not been clearly defined (34-38), low doses of IL-15 may allow selective expansion of $\mathrm{CD}^{+}$ Tregs in vivo. A precedent for such an approach is suggested by recent reports that low-dose IL-2 treatment selectively enhances $\mathrm{CD}^{+}{ }^{+}$Tregs in vivo and can suppress chronic graft-versus-host disease (GVHD) and HCV-related vasculitis after BM transplants (39-41).

We designed Qa-1 R72A-Qdm and Qa-1-Hsp60 $0_{\mathrm{p} 216}$ tetramers to detect and enrich $\mathrm{CD}^{+} \mathrm{T}$ cells specific for these Qa-1-associated ligands. Although immunization of mice with DCs pulsed with the relevant peptide resulted in selective expansion of $\mathrm{CD}^{+}$ $\mathrm{T}$ cells specific for either Qa-1-Qdm or Qa-1-Hsp60 $0_{\mathrm{p} 216}$, only immunization with the latter peptide efficiently inhibited the development of CIA. Moreover, transfer of a small number of Qa-1-Hsp60 ${ }_{\mathrm{p} 216}$ tetramer $^{+} \mathrm{CD}^{+}$cells, but not Qa-1(R72A)-Qdm tetramer ${ }^{+} \mathrm{CD}^{+}$cells, inhibited disease progression in adoptive hosts. The $\mathrm{CD}^{+}$Treg-mediated suppression we observed following transfer of $\mathrm{CD}^{+}$Tregs was selectively exerted on the response to self antigens, since immune responses to foreign proteins (e.g., NP-KLH) were spared (Supplemental Figure 9). Autoreactive $\mathrm{T}_{\mathrm{FH}}$ and $\mathrm{Th} 17$ subsets that are chronically activated by self antigen (e.g., type II collagen) may upregulate stressrelated proteins, including Hsp60, and present peptides derived from them in association with Qa-1 to Qa-1-restricted CD8 ${ }^{+}$ $\mathrm{T}$ cells. Further studies are required for a better understanding of the functional difference between Qa-1-Hsp $60_{\mathrm{p} 216}$ and Qa-1-Qdm-specific CD8 ${ }^{+} \mathrm{T}$ cells. Possibly, differential expansion of $\mathrm{Ly}^{4} 9^{+} \mathrm{CD} 8^{+} \mathrm{T}$ cells by the 2 self peptides may be relevant to their distinct levels of suppressive activity (Figure 1). Inhibitory signaling associated with engagement of the CD94/NKG2A receptor by the Qa-1-Qdm complex expressed by $\mathrm{CD}^{+}$target cells may dampen TCR-dependent activation of $\mathrm{CD}^{+}$Tregs $(19,42)$. The Hsp60-related peptides may also include the Hsp60 signal peptide (Hsp60sp) derived from the leader sequence of Hsp $60_{\mathrm{p} 10-18}$, since a subset of $\mathrm{CD}^{+}$Tregs that recognizes the 
Qa-1-Hsp60sp complex suppresses autoimmunity (43). Further definition of this subset of $\mathrm{CD}^{+}$Tregs requires successful construction of Qa-1-Hsp60sp tetramers.

Analysis of the activity of tetramer ${ }^{+} \mathrm{CD}^{+}$Tregs depended in part on immunization using peptide-pulsed DCs. Since CD8 ${ }^{+}$ Treg are memory cells according to function and surface phenotype $\left(\mathrm{CD} 122^{+} \mathrm{CD} 44^{+} \mathrm{Ly} 49^{+}\right)$, they may also be expanded by antigen in the absence of cell-dependent costimulatory activity. For example, peptide-Qa-1-coated (HLA-E-coated) nanoparticles (NP) may represent an effective and simplified method for $\mathrm{CD}^{+}$ Treg expansion that does not require cellular therapy. Moreover, since both Qa-1 and HLA-E MHC class Ib genes exhibit a limited polymorphism, in contrast with the extensive polymorphisms of MHC class Ia molecules (e.g., HLA-E expression is confined to 2 alleles that differ at a single amino acid), peptide-HLA-E-based immunotherapy should not require extensive individualized peptide-MHC design.

In the present studies, expansion of $\mathrm{CD}^{+}$cells specific for Hsp60 216 (but not a control self peptide) was associated with efficient inhibition of autoimmune arthritis, a reduction of the $\mathrm{T}_{\mathrm{FH}} / \mathrm{Th} 17$ pathogenic Th pair, and diminished autoantibody to mouse collagen. Whether autoreactive Th cells that induce other forms of autoimmunity also can be targeted by Hsp $60_{\mathrm{p} 216}$-specfic $\mathrm{CD}^{+}$Tregs is under investigation. The development of therapeutic strategies based on specific expansion and activation of peptide-specific $\mathrm{CD}^{+}$Tregs represents a new and potentially effective approach to the treatment of autoimmune disease.

\section{Methods}

Mice. B6, B6.Prf1 $1^{-/-}$, Rag2 $^{-/-} \mathrm{Prf1}^{-/-}, \mathrm{IL}-15^{-/-}, \mathrm{Kb}^{-/-} \mathrm{Db}^{-/-}$(Taconic Farms), OT-1 TCR transgenic (Jackson Laboratory), and B6.Qa-1 D227K mice (backcrossed for 11 generations) (18) were housed in pathogen-free conditions.

CIA induction and assessment. cCII (MD Bioscience) was dissolved in $0.01 \mathrm{M}$ acetic acid at a concentration of $4 \mathrm{mg} \mathrm{ml}^{-1}$ by stirring overnight at $4^{\circ} \mathrm{C}$. All mice used were males between the age of 8 and 12 weeks. To induce CIA, B6 mice were injected intradermally (i.d.) at the base of the tail with $150 \mu \mathrm{g}$ of cCII emulsified in CFA (supplemented with $4 \mathrm{mg} \mathrm{ml}^{-1}$ Mycobacterium tuberculosis) and boosted at day 21 with $100 \mu \mathrm{g}$ of cCII emulsified in IFA. A cocktail of 4 monoclonal Abs (1 mg; MD Bioscience) binding to cCII was used to induce arthritis, as shown in Figure 3B. For adoptive transfers, $\mathrm{CD} 4^{+}\left(\mathrm{CD} 25^{+} \mathrm{CD} 4^{+}\right.$Treg depleted) and $\mathrm{B}$ cells were purified as described previously (5) from arthritic mice and then intravenously injected into $\mathrm{Rag}^{-1-} \mathrm{Prf1}^{-/-}$hosts along with FACS-sorted $\mathrm{CD}^{+}$ or $\mathrm{CD}^{+}$Tregs with indicated surface phenotype before immunization at day 0 and boosting at days 21 and 35 . Clinical assessment of CIA was performed every 2-3 days each week, and scoring was as follows: 0 , normal; 1 , mild swelling and/or erythema confined to the mid-foot or ankle joint; 2 , moderate edematous swelling extending from the ankle to the metatarsal joints; and 3, pronounced swelling encompassing the ankle, foot, and digits. Each limb was graded, allowing a maximum score of 12 per mouse.

Measurement of Abs against CII. Serum levels of anti-mouse CII IgG were measured by ELISA after serum collection at the indicated days after initial cCII immunization. Briefly, 96-well ELISA microplates were coated with mouse $\mathrm{CII}$ (Chondrex) at $5 \mu \mathrm{g} \mathrm{ml}^{-1}$ dissolved in dilution buffer (Chondrex) at $100 \mu \mathrm{l} /$ well at $4^{\circ} \mathrm{C}$ overnight. $100 \mu \mathrm{l}$ of diluted serum sample was incubated for 2 hours at room temperature. The plates were washed with PBST (0.05\% Tween-20 in PBS) 5 times, followed by addition of peroxidase-conjugated goat anti-mouse IgG at 1:50,000 (Sigma-Aldrich) at $100 \mu \mathrm{l} /$ well. After 1 hour incubation at room temperature and wash, the final color development was achieved by adding TMB substrate (BD Bioscience) to each well at $100 \mu \mathrm{l} /$ well, and absorbance was measured at $405 \mathrm{~nm}$ at the appropriate time.

Flow cytometry. Spleen and LNs were excised, and single-cell suspensions were prepared. Draining LNs (dLN) included popliteal and inguinal LNs; non-draining LNs (non-dLN) were axillary, cervical, and mesenteric LNs. For isolation of intraarticular cells, paw pieces were isolated and digested with collagenase/dispase (Roche) for 1 hour at $37^{\circ} \mathrm{C}$ followed by filtration to yield single-cell suspensions. Cells were incubated with Fc block for 15 minutes followed by staining with various Abs against surface markers or Qa-1 tetramers. CD45 marker was included to gate leukocytes from joints for further analysis. For intracellular cytokine staining, cells were restimulated with leukocyte activation cocktail (BD Bioscience) for 5 hours, stained with surface markers, fixed, and permeabilized, followed by incubation with indicated Abs. Cells were acquired on a FACSCanto II using FACSDIva software (BD Biosciences) and analyzed with FlowJo software (Tristar). Mouse-specific Abs to CD8 $\alpha$, TCR- $\beta$, CD44, CD45, CD62L, CD25, B220, Fas, CXCR5, IFN- $\gamma$, IL-17, ICOS, IgM, Ly49A ${ }^{\text {B6 } 6}$, Ly49G2, Ly49F, Ly49C/I, and NK1.1 were purchased from BD Bioscience. Abs to Ly49C/I/F/H, CD122, BTLA, IL-21, NKG2 $\mathrm{A}^{\mathrm{B} 6}$, and Foxp3 were purchased from eBioscience.

In vitro differentiation of Th17 subsets and adoptive transfer. Cells from spleen and LNs were collected from B6 mice immunized with $150 \mu \mathrm{g} \mathrm{cCII/CFA,}$ and $\mathrm{CD} 4^{+} \mathrm{CD} 25^{-}$cells were purified and enriched using negative selection. $2 \times 10^{5} \mathrm{ml}^{-1} \mathrm{CD}^{+}$cells were stimulated with $100 \mu \mathrm{g} \mathrm{m}{ }^{-1} \mathrm{cCII}$ in the presence of $2 \times 10^{6}$ irradiated total splenocytes. For differentiation of CD4 ${ }^{+}$ cells to Th17 cell phenotype, the following cytokine cocktail was added to cultures: $3 \mathrm{ng} \mathrm{ml}^{-1}$ TGF- $\beta$, $20 \mathrm{ng} \mathrm{ml}^{-1} \mathrm{rIL}^{-6,}, 20 \mathrm{ng} \mathrm{ml}^{-1} \mathrm{rIL}^{-23,} 10 \mu \mathrm{g} \mathrm{ml}^{-1}$ anti-IL-12 Ab, $10 \mu \mathrm{g} \mathrm{ml}^{-1}$ anti-IFN- $\gamma \mathrm{Ab}, 10 \mu \mathrm{g} \mathrm{ml}^{-1}$ anti-IL-4 Ab. At day 5 , live $\mathrm{CD} 4^{+}$cells were harvested from cultures by Percoll gradient centrifugation and used for adoptive transfer. Confirmation of Th17 phenotype was performed using FACS analysis of IL-17 expression or using RT-PCR for detection of transcription factor Rorc (19).

Generation of WT and R72A mutant Qa-1 tetramers. A standard tetramer generation protocol was used, as described previously $(44,45)$. Briefly, an R72A mutant Qa-1 construct was generated using the QuikChange II Site-Directed Mutagenesis Kit (Stratagene) on a WT Qa-1 construct that contained biotin-binding sites for conjugation of monomers to form tetramers. Constructs were then used to transform Rosetta 2 (DE3) competent cells, and inclusion bodies were purified and stored at $-80^{\circ} \mathrm{C}$. For analysis of refolding capacity of each individual peptide, candidates were refolded with either WT or R72A mutant Qa-1 heavy chain in the presence of $\beta_{2} \mathrm{~m}$. The refolding solution was then analyzed by size exclusion chromatography for a distinctly refolded Qa- $1 / \beta_{2} \mathrm{~m} /$ peptide peak that was collected as a monomer and stored at $-80^{\circ} \mathrm{C}$ before conjugation with streptavidin-phycoerythrin or streptavidin-allophycocyanin to form tetramers prior to each use.

Enrichment for tetramer-positive cells. Single-cell suspensions from spleen and LNs of cCII-immune B6 mice were incubated with anti-CD8 $\alpha$, anti-TCR- $\beta$ and PE-labeled Qa-1 tetramers for 30 minutes at room temperature followed by sorting for tetramer-positive and tetramer-negative CD $8 \alpha^{+}{ }^{T C R} \beta^{+}$cells on a BD FACSAria cell sorter (BD Bioscience). Sorted cells were incubated with IL-15C $\left(10 \mathrm{ng} \mathrm{ml}^{-1}\right)$ for 10 days before further enrichment of tetramer-positive cells as described (10). Briefly, cultured cells were washed and incubated with PE-labeled Qa-1 tetramers for 30 minutes at room temperature followed by washing and resuspension in sorter buffer. Anti-PE microbeads (Miltenyi Biotec) were added to each sample and incubated for 15 minutes at $4^{\circ} \mathrm{C}$. Cells were washed, and PElabeled cells were isolated by passage over an LS magnetic column (Miltenyi Biotec) followed by reanalysis of tetramer staining and adoptive transfer.

Statistics. Statistical analyses were performed using 2-tailed Student's $t$ test or Mann-Whitney test for comparison of 2 conditions. Error bars denote mean \pm SEM. A $P$ value of $<0.05$ was considered to be statistically significant. 
Study approval. All experiments involving vertebrates were performed in compliance with federal laws and institutional guidelines and approved by the Dana-Farber Cancer Institute Animal Care and Use Committee.

\section{Acknowledgments}

This work was supported in part by NIH research grant AI 037562, a collaborative research agreement with NovoNordisk A/G, and a gift from the LeRoy Schecter Research Foundation to H. Cantor; and a Swedish Research Council Award and VINNMERMarie Curie international qualification (VINNOVA, 2011-03458) to X. Wang.J.W. Leavenworth is an National Research Service Award fellow (T32 CA070083); X. Tang is an NRSA fellow (T32 CA 009382); H.-J. Kim is a scholar of the Arthritis National Research Foundation. We thank C. Schellack Wenander for critical reading and insightful comments and A. Angel for manuscript and figure preparation.

Received for publication September 18, 2012, and accepted in revised form December 13, 2012.

Address correspondence to: Harvey Cantor, Dana-Farber Cancer Institute, 450 Brookline Ave., Boston, Massachusetts 02215 USA. Phone: 617.632.3348; Fax: 617.632.4630; E-mail: Harvey_Cantor@ dfci.harvard.edu.
1. Asquith DL, Miller AM, McInnes IB, Liew FY. Animal models of rheumatoid arthritis. Eur J Immunol. 2009;39(8):2040-2044.

2. Cho YG, Cho ML, Min SY, Kim HY. Type II collagen autoimmunity in a mouse model of human rheumatoid arthritis. Autoimmun Rev. 2007;7(1):65-70.

3. Bevaart L, Vervoordeldonk MJ, Tak PP. Evaluation of therapeutic targets in animal models of arthritis: how does it relate to rheumatoid arthritis? Arthritis Rheum. 2010;62(8):2192-2205.

4. Vinuesa CG, Tangye SG, Moser B, Mackay CR. Follicular B helper T cells in antibody responses and autoimmunity. Nat Rev Immunol. 2005;5(11):853-865.

5. Kim HJ, Verbinnen B, Tang X, Lu L, Cantor H. Inhibition of follicular $\mathrm{T}$ helper cells by $\mathrm{CD} 8^{+}$ Treg is essential for self tolerance. Nature. 2010; 467(7313):328-332.

6. Crotty S. Follicular helper CD4 T cells (TFH). Annu Rev Immunol. 2011;29:621-663.

7. Hu D, Ikizawa K, Lu L, Sanchirico ME, Shinohara ML, Cantor H. Analysis of regulatory CD8 T cells in Qa-1-deficient mice. Nat Immunol. 2004; 5(5):516-523.

8. Strange A, et al. A genome-wide association study identifies new psoriasis susceptibility loci and an interaction between HLA-C and ERAP1. Nat Genet. 2010;42(11):985-990.

9. Evans DM, et al. Interaction between ERAP1 and HLA-B27 in ankylosing spondylitis implicates peptide handling in the mechanism for HLA-B27 in disease susceptibility. Nat Genet. 2011;43(8):761-767.

10. Nagarajan NA, Gonzalez F, Shastri N. Nonclassical MHC class Ib-restricted cytotoxic T cells monitor antigen processing in the endoplasmic reticulum. Nat Immunol. 2012;13(6):579-586.

11. Fruci D, et al. Altered expression of endoplasmic reticulum aminopeptidases ERAP1 and ERAP2 in transformed non-lymphoid human tissues. J Cell Physiol. 2008;216(3):742-749.

12. Michaelsson J, Teixeira de Matos C, Achour A, Lanier LL, Karre K, Soderstrom K. A signal peptide derived from hsp60 binds HLA-E and interferes with CD94/NKG2A recognition. J Exp Med. 2002; 196(11):1403-1414.

13. Davies A, et al. A peptide from heat shock protein 60 is the dominant peptide bound to Qa-1 in the absence of the MHC class Ia leader sequence peptide Qdm. J Immunol. 2003;170(10):5027-5033.

14. Lu L, Ikizawa K, Hu D, Werneck MBF, Wucherpfennig KW, Cantor $\mathrm{H}$. Regulation of activated CD4+ T cells by NK cells via the Qa-1-NKG2A pathway. Immunity. 2007;26(5):593-604.

15. Moon JJ, et al. Tracking epitope-specific T cells. Nat Protoc. 2009;4(4):565-581.

16. Kim HJ, Wang X, Radfar S, Sproule TJ, Roopenian DC, Cantor H. CD8+ T regulatory cells express the Ly49 class I MHC receptor and are defective in autoimmune-prone B6-Yaa mice. Proc Natl Acad Sci US A. 2011;108(5):2010-2015.

17. Kamphuis S, et al. Tolerogenic immune responses to novel T-cell epitopes from heat-shock protein 60 in juvenile idiopathic arthritis. Lancet. 2005; 366(9479):50-56.

18. Lu L, Kim HJ, Werneck MB, Cantor H. Regulation of CD8+ regulatory $\mathrm{T}$ cells: Interruption of the NKG2A-Qa-1 interaction allows robust suppressive activity and resolution of autoimmune disease. Proc Natl Acad Sci U S A. 2008;105(49):19420-19425.

19. Leavenworth JW, Wang X, Wenander CS, Spee P, Cantor H. Mobilization of natural killer cells inhibits development of collagen-induced arthritis. Proc Natl Acad Sci USA. 2011;108(35):14584-14589.

20. Rubinstein MP, et al. Converting IL-15 to a superagonist by binding to soluble IL-15R \{alpha\}. Proc Natl Acad Sci U S A. 2006;103(24):9166-9171.

21. Stoklasek TA, Schluns KS, Lefrancois L. Combined IL-15/IL-15Ralpha immunotherapy maximizes IL-15 activity in vivo. J Immunol. 2006;177(9):6072-6080.

22. Cronstein BN. Low-dose methotrexate: a mainstay in the treatment of rheumatoid arthritis. Pharmacol Rev. 2005;57(2):163-172.

23. Chan ES and Cronstein BN. Methotrexate - how does it really work? Nat Rev Rheumatol. 2010; 6(3):175-178.

24. Müller-Ladner U, Ospelt C, Gay S, Distler O, Pap T. Cells of the synovium in rheumatoid arthritis. Synovial fibroblasts. Arthritis Res Ther. 2007;9:223.

25. Morgan ME, et al. CD25+ cell depletion hastens the onset of severe disease in collagen-induced arthritis. Arthritis Rheum. 2003;48(5):1452-1460.

26. Kelchtermans H, et al. Defective CD4+CD25+ regulatory $\mathrm{T}$ cell functioning in collagen-induced arthritis: an important factor in pathogenesis, counter-regulated by endogenous IFN-gamma. Arthritis Res Ther. 2005;7(2):R402-R415.

27. Oh S, Rankin AL, Caton AJ. CD4+CD25+ regulatory $\mathrm{T}$ cells in autoimmune arthritis. Immunol Rev. 2010; 233(1):97-111.

28. Fields ML, et al. CD4+ CD25+ regulatory T cells inhibit the maturation but not the initiation of an autoantibody response. I Immunol. 2005; 175(7):4255-4264.

29. Frey $\mathrm{O}$, et al. The role of regulatory $\mathrm{T}$ cells in antigen-induced arthritis: aggravation of arthritis after depletion and amelioration after transfer of CD4+CD25+ T cells. Arthritis Res Ther. 2005; 7(2):R291-R301.

30. Korn T, Oukka M, Kuchroo V, Bettelli E. Th17 cells: effector T cells with inflammatory properties. Semin Immunol. 2007;19(6):362-371.

31. Chung $Y$, et al. Follicular regulatory $T$ cells expressing Foxp3 and Bcl-6 suppress germinal center reac- tions. Nat Med. 2011;17(8):983-988.

32. Linterman MA, et al. Foxp3(+) follicular regulatory $\mathrm{T}$ cells control the germinal center response. Nat Med. 2011;17(8):975-982.

33. KimHJ and Cantor H. Regulation of self tolerance by Qa-1-restricted CD8+ regulatory T cells. Semin Immunol. 2011;23(6):446-452.

34. Ruchatz H, Leung BP, Wei XQ, McInnes IB, Liew FY. Soluble IL-15 receptor alpha-chain administration prevents murine collagen-induced arthritis: a role for IL-15 in development of antigeninduced immunopathology. I Immunol. 1998; 160(11):5654-5660.

35. Amlong CA, Nardelli DT, Peterson SH, Warner TF, Callister SM, Schell RF. Anti-interleukin-15 prevents arthritis in Borrelia-vaccinated and -infected mice. Clin Vaccine Immunol. 2006;13(2):289-296.

36. Benito-Miguel M, et al. A dual action of rheumatoid arthritis synovial fibroblast IL-15 expression on the equilibrium between $\mathrm{CD} 4+\mathrm{CD} 25+$ regulatory $\mathrm{T}$ cells and CD4+CD25- responder T cells. J Immunol. 2009;183(12):8268-8279.

37. Wu X, Pan W, He Y, Hsuchou H, Kastin AJ. Cerebral interleukin-15 shows upregulation and beneficial effects in experimental autoimmune encephalomyelitis. J Neuroimmunol. 2010;223(1-2):65-72.

38. Gomez-Nicola D, Spagnolo A, Guaza C, NietoSampedro M. Aggravated experimental autoimmune encephalomyelitis in IL-15 knockout mice. Exp Neurol. 2010;222(2):235-242.

39 . Bluestone JA. The yin and yang of interleukin2-mediated immunotherapy. N Engl J Med. 2011; 365(22):2129-2131.

40. Koreth J, Matsuoka K, Kim HT, McDonough SM, Bindra B, Alyea EP. Interleukin-2 and regulatory $\mathrm{T}$ cells in graft-versus-host disease. $N$ Engl J Med. 2011;165(22):2055-2066

41. Saadoun D, et al. Regulatory T-cell responses to low-dose interleukin-2 in $\mathrm{HCV}$-induced vasculitis. NEngl J Med. 2011;365(22):2067-2077.

42. Leavenworth JW, Schellack C, Kim HJ, Lu L, Spee $\mathrm{P}$, Cantor H. Analysis of the cellular mechanism underlying inhibition of EAE after treatment with anti-NKG2A F(ab')2. Proc Natl Acad Sci U S A. 2010;107(6):2562-2567.

43. Wu Y, Zheng Z, Jiang Y, Chess L, Jiang H. The specificity of $T$ cell regulation that enables self-nonself discrimination in the periphery. Proc Natl Acad Sci US A. 2009;106(2):534-539.

44. Altman JD, et al. Phenotypic analysis of antigen-specific T lymphocytes. Science. 1996;274(5284):94-96.

45. Wang R, Ramaswamy S, Hu D, Cantor H. Definition of a novel binding site on CD8 cells for a conserved region of the MHC class Ib molecule Qa-1 that regulates IFN-gamma expression. Eur J Immunol. 2001;31(1):87-93. 